«Кемеровского завода «Коммунар», для современного подрастающего поколения, показать ту цену, которую заплатили практически все семьи трудового региона.

\section{Список литературы}

1. Специалисты по взрывчатым материалам, пиротехнике и боеприпасам: биогр. энцикл. Москва, 2006. $701 \mathrm{c}$.

2. ГАКО. Ф.200. Оп.1. Д.55. Л. 11-12; Д.69. Л.25, 27, 38; Д.94. Л.32-33; Д.121. Л.13, 33, 40, 72.

3. ГАКО. Ф.204. Оп.3. Д.1. Л.37, 284, 345, 415; Д.2. Л.61, 111, 323; Ф.304. Оп.4. Д.3990. Л.1-2; Д.3995. Л.11-13.
4. Болтовский О. В. Создание и деятельность завода № 319 в военные годы // Город Кемерово в годы Великой Отечественной войны. Кемерово, 2000. 156 с.

5. ГАКО. Ф.75-П. Оп. 1. Д.33. Л.1, 9, 10, 21-23,41-42, 46-47; Ф.304. Оп. 4. Д.3971. Л.77; Д.4684. Л.10, 16, 21.

6. Шуранов Н. П. Кузбасс в годы Великой Отечественной войны. Кемерово, 2000. 179 с.

7. Кировский район. Вехи истории: 19342009. Кемерово, 2009. 159 с.

8. ГАКО. Ф.75-П. Оп. 1. Д4. Л.4-5, 13,16 , 18; Ф.304. Оп.4. Д.54. Л.18; Д.3972. Л.11-12, 26; Ф.461. Оп.2. Д.2. Л.10, 191; Ф.797. Оп.1. Д.133. Л.42-43.

УДК 130.2:342.813+159.924.24

DOI: $10.32340 / 2514-772 X-2021-1-40-43$

И. Н. Каланчина, кандидат философских наук, доцент Алтайский государственный аграрный университет (Барнаул, Россия) kalanchina62@mail.ru

\title{
АКСИОЛОГИЧЕСКАЯ ЛИНГВОМЕТОДИКА КАК СРЕДСТВО АКТУАЛИЗАЦИИ ЛИЧНОСТНОГО НАЧАЛА В ПЕДАГОГИЧЕСКОЙ ПРАКТИКЕ
}

Аннотация. Проблема реализации интеллектуальных, творческих способностей современной молодежи имеет множество аспектов. Среди них важное место занимает наличие идейного компонента в содержании воспитательных и образовательных программ. По мнению автора, применение принципов природосообразности, идеалосообразности и аксиологической лингвометодики позволяет «пробудить» индивидуальность студента, так как ценностный подход является очень важным для формирования зрелой личности.

Ключевые слова: философия образования, иенностно-ориентированный подход в образовании, философия культуры, аксиологическая лингвометодика.

Образование в его подлинном значении является важнейшим фактором развития как отдельного человека, так и всего общества. Поэтому важным критерием, определяющим, насколько успешно система образования выполняет данную функцию, является показатель реализации личностного начала и учащегося, и преподавателя. И совершенно очевидно, что современную ситуацию с этой точки зрения трудно назвать благополучной.

Проблема реализации интеллектуальных, творческих способностей современной молодежи (самого широкого диапазона: от детей дошкольного возраста до выпускников колледжей и вузов) имеет множество аспектов. Среди них можно отметить, такие как уровень и качество государственного управления и законодательно- правовая база в сфере воспитания и образования, социальный статус педагога (воспитателяучителя-преподавателя), уровень соответствия идейной составляющей (ее глубокая проработка или же формальная имитация работы в этом направлении) национальным интересам сохранения суверенитета и всестороннего развития государства и др.

В данной статье мы остановимся на одном из важных аспектов - идейном содержании воспитательно-образовательного процесса, а конкретно - насколько оптимально используются в воспитательно-образовательном процессе возможности предметов гуманитарного цикла и, особенно русского языка и производных от него дисциплин (в частности, русский язык и культура речи, деловое общение, речевая культура 
педагога и пр. Необходимо отметить, что в последнее время, специалисты системы образования стали больше, чем прежде, уделять внимания воспитательной работе, в том числе и патриотическому воспитанию. С одной стороны, это позитивная тенденция и ее можно только приветствовать, с другой стороны, многим профессионалам в области педагогики очевидны существенные погрешности, связанные, как ни странно это будет звучать, со слабой проработанностью идейной составляющей большинства современных воспитательных программ и проистекающей из этого их невысокой эффективностью.

На наш взгляд, причина скрывается в том, что 90-е гг. XX века на уровне социального управления был взят курс на отказ от национальной идеологии, что сразу же проявилось и в сфере образования. Поэтому, несмотря на то, что сегодня такой подход пересмотрен, тем не менее, существует много недоработок, связанных с отсутствием преемственности, разрывом в педагогической традиции и утерянными воспитательными методиками.

Идеологическая составляющая - вопрос очень сложный и требует привлечения авторитетных экспертов из самых разных областей социальной философии, культурологи, социологии, истории, права, педагогики, психологии и пр. Но вот идейная сторона воспитательной работы в образовательных учреждениях, если опираться на лучшие достижения в области отечественной культуры, искусства, возможностей гуманитарных дисциплин, - может и должна быть продумана и воплощена в реальной педагогической практике.

Остановимся на воспитательных возможностях нашего «великого и могучего» русского языка и применении их в высших учебных заведениях. Опираясь на личный опыт, автор данной статьи может отметить, что потенциал специальной системы заданий при преподавании русского языка и других гуманитарных предметах очень высокий и его необходимо популяризировать и применять. И в этом смысле важно не столько собрать в «педагогическую копилку» уже применяемые разработки, сколько вооружиться системой принципов и методических подходов.

Как утверждал выдающийся мыслитель, педагог С. И. Гессен, педагог в своей деятельности должен ориентироваться на некие методологические основы, руководствоваться общими принципами. Предписывать конкретные правила («технологии») того, как должен быть организован урок - «...значило бы впадать в недостойную научной педагогики рецептуру. Вся суть нашего принципа в том и состоит, что он есть лишь руководящий, регулятивный принцип, который в каждом отдельном случае каждым отдельным воспитателем должен применяться в жизни по-своему - сообразно детям, воспитателю и обстоятельствам... Не следовать чужим рецептам, но создавать свое должен воспитатель. И поэтому научная педагогика тоже должна предлагать не рецепты организации игры, но лишь регулятивные принципы, в направлении которых игра должна быть организуема каждый раз по-новому. Искусство воспитателя здесь и состоит в том, чтобы быть творцом» $[1$, c. 97-98].

На наш взгляд, если говорить о гуманистической педагогике и высоком идейном содержании воспитательной работы, то, естественно, такими основополагающими принципами как раз и являются природосообразность и идеалосообразность. Только на их основе может раскрыться личностное начало и наставника, и учеников. В этом смысле работу учителя можно сравнить с творчеством, скажем, музыканта: настоящий учитель всегда имеет свое собственное видение, замысел исполнения каждой «педагогической партитуры», индивидуально окрашивая каждое свое педагогическое действие. Вне этих условий его труд будет носить формальный характер, а потому останется обезличенным и непродуктивным.

Принцип природосообразности имеет богатую историю, и в течение многих веков насыщался все более ясным, многомерным содержанием, интегрирующим философские, психологические, педагогические, естественнонаучные знания. Этот принцип опирается на традицию целостного осмысления мира и человека в их неразрывном единстве и, соответственно, предполагает согласование методов обучения и воспитания с законами психофизиологического развития человека, закономерностями самого социально-педагогического процесса и индивидуальными особенностями личности ученика. Иными словами, принцип природосообразности - это установка на такое обучение и воспитание, которое гармонично резонирует с биологической, психологической, социальной и духовной природой человека.

Ведя речь об идеалосообразности, мы предполагаем в качестве обязательного условия наличие ценностной иерархии и устойчивых представлений о добре и зле, воплощающихся в личностном идеале, к которому устремляются и 
ученик, и учитель в процессе обучения и воспитания. Если нет такого высокого образца, то утрачивается и цель образования [2, с. 79-82].

Третьим важным принципом, который мы применяем и в учебном, и в воспитательном процессе, это ценностно-ориентированный подход. Идея о целесообразности экспликации ценностного содержания языка и классических текстов получила развитие в трудах автора $а \kappa-$ сиологической лингвометодики (как одного из методов иенностно-ориентированного подхода - применительно к преподаванию русского языка и литературы) профессора Л. Д. Дейкиной еще в 70-90 гг. ХХ в.

Базовые принципы данной методики можно свести к следующему:

1. Ценностные установки учащихся являются методическим понятием со своим содержанием и объемом, что значительно шире традиционной системы знаний и компетенций.

2. Учебный (воспитательный) процесс должен быть организован так, чтобы учащийся как субъект процесса познания и общения осознанно освоил систему ценностей, закрепленных в языке.

3. Основой изучения русского языка является, помимо фонетики, лексики и грамматики, усвоение норм этики, нравственности, морали, принятых в русской культуре.

4. При интерпретации учебного материала аксиологическая методическая идея является системообразующей в силу уникальности русского языка как культурно-национального феномена, в котором проявляется ценностный мир русского человека.

5. Аксиологический подход при работе с языком и текстами значительно повышает мотивацию, так как обучение ориентируется и направлено на активизацию эмоционального интеллекта учащихся [3, с. $11-19]$.

Аксиологическая лингвометодика, по сути, опирается на учение о природе взаимодействия языка, сознания и культуры, высказанные известными русскими мыслителями, занимавшимися исследованиями в области философии языка. Результаты этих исследований сыграли важную роль в развитии представления о том, что язык - не просто набор условных символов для передачи информации, но сложнейшая система мета-смыслов, коррелирующих с реальностью и когнитивными процессами в сознании человека.

Так, видный представитель русской философской мысли П. Д. Юркевич отмечал, что слова связаны с мышлением, с идеей и с психическими процессами, со всем внутренним, духовным миром человека. В работах его современника В. С. Соловьева язык предстает как предмет и объект реализации синтеза таких сфер познания, как философия, культура, лингвистика, психология, антропология, гносеология и др. По мнению философа, способность языка эксплицировать не только результаты работы интеллекта человека, но также переживания и другие психические состояния, делает его универсальным средством выражения цельного знания о бытии в целом. Важным моментом в процессе познания является всеобщность значения. При этом слово является необходимой материальной основой мыслительной деятельности человека, способом выражения ее результатов. В то же время, В. С. Соловьев замечал, что «слово создает своему содержанию новое единство, не бывшее в наличности непосредственного сознания», упраздняет отдельность ощущений и оставляет общее и постоянное в обозначаемом. «Слово придает мышлению форму всеобщности, что означает свободу от эмпирических условий субъективного психического процесса. Слово есть собственная стихия логического мышления, которое без слов так же невозможно, как воздух без кислорода и вода без водорода» [4, с. 807-810].

Действительно, язык - это уникальный инструмент, который помогает человеку познавать окружающий мир, других людей, различные культурные процессы, самого себя и одновременно развивать свой мыслительный аппарат. А применительно к образцовым текстам русской классики (к ним мы относим произведения художественной литературы, устного народного творчества, публицистики, журналистики, философских трактатов, чьи авторы заслужили всеобщее признание и пользуются безусловным авторитетом) - можно заметить, что гениальные мастера слова и отличаются тем, что, уделяя большое внимание иенностной составляющей, учат своих читателей глубоко понимать и переживать единство с историей народа, своей культурной средой, другими людьми, а через это - и с миром в целом.

В связи с этим необходимо еще раз отметить яркую самобытность, высокий интеллектуальный и художественный уровень русской классической литературы, которая в XIX веке достигла небывалого расцвета, завоевав для России признание всего мира и став «визитной карточкой» для всей русской культуры. Литера- 
тура в России никогда не была просто изящной игрой слов, а призвана отражать важнейшие вопросы и принципы бытия человека и мира. Поиск смысла жизни, который в русской литературе так востребован и настоятелен, как ни в какой другой. И хотя у разных авторов он раскрывается в различных формах и образах, общее смысловое ядро всегда остается неизменным. Если попытаться обобщить суть этих поисков и интерпретировать их в ракурсе иенностноориентированного подхода, то, по мнению русских классиков, смысл жизни заключается в том, чтобы человек, постигая высшие идеалы и законы бытия, неуклонно применял их в своей жизни и тем самым совершенствовал свою человеческую природу и мир вокруг себя. При этом в России литература всегда являлась концентрированным выражением национального идеала, вбирая в себя самые высокие мысли и устремления.

Неслучайно так высоко оценивают русскую литературу интеллектуалы во всех странах мира. Показательно мнение «со стороны» - современного зарубежного ученого, профессора из Китая Лю Вэньфэя, который убежден, что высокий художественный уровень, нравственный заряд, реалистичность и философичность русской литературы проистекают из особенностей национального характера. По его мнению, поскольку «Россия простирается от Европы до Азии, эта «евразийность» является, как с гордостью заявляют русские, основой их уникальности. Можно сказать, что в то время, как люди Запада отличаются рациональным, аналитическим складом ума, а люди Востока больше внимания уделяют чувствам и ценят синтез больше анализа, русские находятся где-то посередине и поэтому объединяют в себе разум и эмоции, анализ и синтез, и литературоцентричная мысль или идейно нагруженная литература могут быть наиболее блестящим проявлением этой модели мышления» [5].

А известный критик рубежа XIX-XX веков М. Арнольд отмечал, что с конца XIX в области мировой литературы «французы и англичане потеряли первенство», оно перешло к «стране, демонстрирующей новое в литературе... Русский роман ныне определяет литературную моду. Мы все должны учить русский язык» [6].
Таким образом, к основным обучающим возможностям применения аксиологической лингвометодики при изучении произведений русских классиков целесообразно отнести:

1) глубокое постижение учащимися российского культурного наследия;

2) большой выбор возможностей для разнообразия творческих заданий, которые можно разработать на основе данного материала;

3) высокая эффективность развивающего, обучающего и воспитательного потенциала текстов;

4) обеспечение условий не только для обмена информацией, но и для обсуждения философских, психологических, культурных, ментальных проблем, т.е. для выхода на новый более высокий уровень коммуникации.

Возвращаясь к проблеме, вынесенной в название данной статьи, можно резюмировать, что применение принципов природосообразности, идеалосообразности и аксиологического подхода при преподавании гуманитарных дисциплин и в воспитательной работе в вузе позволяет «пробудить» индивидуальность студента, так как происходит формирование ценностной сферы, которая является очень важной для формирования зрелой личности.

\section{Список литературы}

1. Гессен С. И. Основы педагогики. Введение в прикладную философию. Москва, 1995. $87 \mathrm{c}$.

2. Каланчина И. Н. Личность в образовании: история и современность. Барнаул, 2005. $134 \mathrm{c}$.

3. Дейкина А. Д. Аксиологическое значение методики преподавания великого и могучего русского языка // Аксиологическая лингвометодика: материалы международной научнопрактической конференции, в 2 частях. Часть 1. Москва, 2019. С. 11-19.

4. Гиляров-Платонов Н. П. Экскурсии в русскую грамматику. Москва, 1904. 63 с.

5. Вэньфэй Лю. Как русская литература сформировала русскую общественную мысль. URL:

https://inosmi.ru/russia/20130520/209163627.html (23.02.2021).

6. Берковский Н. Я. Мировое значение русской литературы. Москва, 1975. 184 с. 